\title{
Chambers for International Commercial Disputes in Germany: The State of Affairs
}

\author{
Burkhard Hess \& Timon Boerner*
}

\section{Abstract}

The prospect of attracting foreign commercial litigants to German courts in the wake of Brexit has led to a renaissance of English-language commercial litigation in Germany. Leading the way is the Frankfurt District Court, where - as part of the 'Justizinitiative Frankfurt' - a new specialised Chamber for International Commercial Disputes has been established. Frankfurt's prominent position in the financial sector and its internationally oriented bar support this decision. Borrowing best practices from patent litigation and arbitration, the Chamber offers streamlined and litigant-focused proceedings, with English-language oral hearings, within the current legal framework of the German Code of Civil Procedure (ZPO). ${ }^{1}$

However, to enable the complete litigation process - including the judgment - to proceed in English requires changes to the German Courts Constitution Act ${ }^{2}$ (GVG). A legislative initiative in the Bundesrat aims to establish a suitable legal framework by abolishing the mandatory use of German as the language of proceedings. Whereas previous attempts at such comprehensive amendments achieved only limited success, support by several major federal states indicates that this time the proposal will succeed.

With other English-language commercial court initiatives already established or planned in both other EU Member States and Germany, it is difficult to anticipate whether - and how soon - Frankfurt will succeed in attracting English-speaking foreign litigants. Finally, developments such as the 2018 Initiative for Expedited B2B Procedures of the European Parliament or the ELI-UNIDROIT project on Transnational Principles of Civil Procedure may also shape the long-term playing field.

Keywords: Justizinitiative Frankfurt, Law Made in Germany, International Commercial Disputes, Forum Selling, English Language Proceedings

\section{Introduction}

The international litigation landscape for business disputes is in flux: While the effects on international busi-

* Burkhard Hess is the Executive Director of the Max Planck Institute Luxembourg for International, European and Regulatory Procedural Law (MPI Luxembourg). Timon Boerner is a Research Fellow at the MPI Luxembourg

1. Zivilprozessordnung (ZPO).

2. Gerichtsverfassungsgesetz (GVG). ness litigation resulting from Brexit are unclear, ${ }^{3}$ several EU Member States, including Germany, have recently established or are in the process of establishing special courts and chambers for English-language international business litigation. ${ }^{4}$ The key question to be addressed in this context is: What is Germany doing to keep up with growing competition from other judicial hubs in Europe?

Traditionally, German courts and lawmakers have not attached much importance to this question, as they have regarded delivering justice more as a core task of state authority rather than a service to be marketed in the competing world of dispute settlement. ${ }^{5}$ Nevertheless, 'forum selling' has become quite common in some areas of law. ${ }^{6}$ Equally, some German courts have always excelled in specific cross-border cases: exemplars include the district and appellate courts in Hamburg for transportation and commercial cases or the district and appellate courts in Mannheim, Düsseldorf, ${ }^{7}$ and in Munich for patent and IP litigation. While the overwhelming impression within Germany until recently has been that the justice system was performing well and that domestic litigants usually chose German courts, practice revealed a different reality. According to published case law of the High Court of London, a considerable number of German parties have been bringing their disputes before London courts, especially in relation to high-value commercial disputes (six- or sevendigit sums, if not higher). ${ }^{8}$

3. For a first assessment, see B. Hess, 'Back to the Past: Brexit und das europäische internationale Privat- und Verfahrensrecht', IPRax 409 (2016); M. Sonnentag, Die Konsequenzen des Brexit für das Internationale Privat- und Zivilverfahrensrecht (2017).

4. For a comprehensive overview of International Commercial Courts (including the developments in Asia), cf. M. Requejo Isidro, 'International Commercial Courts in the Litigation Market', MPILux Working Paper 2019:2, available at: https://ssrn.com/abstract=3327166 or http://doi:10.2139/ssrn.3327166.

5. H. Rösler, 'Die Europäisierung von IZVR und IPR als Herausforderung für die deutsche Gerichtsorganisation', ZVgIRWiss 533 (2016); E. Themeli, The Great Race of Courts (2018).

6. For a comprehensive analysis of 'forum selling' in the areas of patent law, press law and antitrust Germany and a comparison to the practice in the United States, see S. Bechtold, J. Frankenreiter \& D. Klerman, 'Forum Selling Abroad', Discussion Papers of the Max Planck Institute for Research on Collective Goods Bonn 2018:9.

7. The Düsseldorf District Court processes 500 patent and intellectual property cases per year in three chambers, see A. Wiese, '80 Jahre Patentgericht - Die Geschichte der Düsseldorfer Gerichte im Patentrecht', in T. Kühnen (ed.), Festschrift zum 80-jährigen Bestehen des Patentgerichtsstandortes Düsseldorf zum 1. Oktober 2016 (2016) 597, at 610 ff.

8. Portland Communications, 'Commercial Courts Report 2018' (2018), available at: https://portland-communications.com/pdf/Portlandcommercial-courts-report-2018.pdf (last visited 28 January 2019). 
Since the millennium, the general attitude in Germany has changed. When the Law Society of England and Wales published a brochure ${ }^{9}$ in 2007 , which openly promoted London as an attractive place of litigation, the German Federal Government and the Federal Bar Association reacted with an initiative called 'Law Made in Germany'. ${ }^{10}$ Sponsored by the Federal Ministry of Justice, the Bar Association and the Chambers of Commerce, the initiative aimed to promote the use of German law and the German judicial system, emphasising the widely recognised efficiency of the German legal system and its judiciary in international commercial cases. ${ }^{11}$ However, it remains unclear whether this initiative has generated tangible benefits for the German judicial market. ${ }^{12}$

In 2010, in a bid to increase the competitiveness of German courts as preferred fora of choice, the district courts in Aachen, Bonn, and Cologne offered parties the possibility to argue their case in English. ${ }^{13}$ While section 184 of the German Courts Constitution Act requires the court to conduct proceedings in German, ${ }^{14}$ there are exceptions from this general rule that apply to the hearing. ${ }^{15}$ Thus, English could be used only during the oral hearing, leaving the rest of the dispute litigation process to be conducted in German. This first attempt to open the civil courts to international litigants was not particularly successful ${ }^{16}$ - perhaps because Aachen and Bonn are not major cross-border commerce hubs in Germany. ${ }^{17}$ At the same time, some Federal States started legislative initiatives in the Bundesrat (Second Chamber of Federal Parliament) to change the strict German-language requirement of section 184 of the German Courts Constitution Act. ${ }^{18}$

\section{The 'Justizinitiative Frankfurt'}

With Brexit looming, however, the discussion has regained momentum: In 2016, shortly after the UK European Membership referendum, the so-called 'Justizinitiative Frankfurt' was launched. The underlying idea was an initiative of the Ministry of Justice of the Federal State of Hesse to attract more litigation to the Frankfurt District Court. As Frankfurt am Main is a leading European financial centre, ${ }^{19}$ the initiative should have a greater chance of success given that relevant industries are already there. ${ }^{20}$

\subsection{The Basic Idea of the 'Justizinitiative'}

Hence, in a joint effort of academia, the bar and the judiciary (including the president of the Frankfurt Court of Appeal), a plan was drawn up to transform Frankfurt am Main into a more service-friendly place for litigation. At present, Frankfurt offers a very interesting environment: In addition to being an important banking and financial sector, other substantial sectors such as pharmaceutical and chemical industries are based there. Frankfurt attracts an internationally oriented bar that is supportive of the 'Justizinitiative', ${ }^{21}$ and many major law firms have established branches in Frankfurt. Furthermore, the civil courts in Frankfurt are well experienced in international matters. Due to this background, the Minister of Justice of Hesse decided in March 2017 to proceed with this project. However, instead of changing the pertinent legal framework, the idea was to start bottom-up by setting up a specialised chamber of the Frankfurt District Court that conducts oral hearings in English and simply changing the distribution list of the court accordingly. This provides the benefit that a foreign party who does not speak German but understands English can attend and understand the proceedings of the specialised chamber and does not require a translation.

19. See the report 'Building Bridges - Frankfurt and Europe after Brexit', available at: https://frankfurt-main-finance.com/neuer-finanzstandort bericht-building-bridges-frankfurt-in-zeiten-des-brexit/; Helaba Volkswirtschaft/Research, 'Brexit-Let's go Frankfurt', available at: https:// www.helaba.de/blob/helaba/407460/

ec93e042e5c3bbd7054e77121d7436d7/finanzplatz-fokus-20161103data.pdf.

20. Düsseldorf, with its rise to prominence in patent litigation matters, is a good example: After the Second World War, there was a specialised bar for patent litigation in Berlin, but Berlin was no longer a marketplace for patents. Therefore, the law firms contacted different ministries of justice and courts of appeal in Germany - first Munich, then Düsseldorf and Cologne - inquiring whether there would be an opportunity to leave Berlin and move there. In Munich, no major interest was shown at the time, but the reaction was different in Düsseldorf. As a result, the specialised law firms moved from Berlin to Düsseldorf, where they created a service-friendly environment, backed by the judiciary and by the local ministry of justice. Today, Düsseldorf has become a prominent place for patent and intellectual property litigation in Europe; see Wiese, above n. 7, at $605 \mathrm{ff}$.

21. For a collection of predominantly positive reactions by members of the bar, see 'Ein richtiger erster Schritt auf einem langen Weg', 4 Deutscher AnwaltSpiegel 17, at 18 ff. (2018). 
The design of proceedings had to be based on the German Code of Civil Procedure (ZPO), but it also takes up best practices of commercial litigation used in other commercial courts, especially the Düsseldorf District Court. ${ }^{22}$ Further strategic elements include actively promoting the new chamber and providing all necessary information to possible litigants. In summary, the justice initiative comprises the following elements: (1) English as the language of procedure, (2) the use of the possibilities of the German Procedural Lams to make proceedings effective, ${ }^{23}$ and (3) a comprehensive communication strategy.

However, it is not enough to just set up a new dispute resolution body within the court system and wait for litigants to show up. In international cases, jurisdiction is often based on choice-of-court agreements (Article 25 Brussels Ibis Regulation). ${ }^{24}$ Therefore, it will take some time until more English-language disputes (arising from newly concluded contracts providing for court agreements) fill the docket at the District Court. ${ }^{25}$

At the same time, cautious optimism is warranted, with a first case transferred to the Chamber for International Commercial Disputes in December 2018. ${ }^{26}$ Additionally, recent experiences in financial litigation demonstrate that already-existing financial instruments, such as the ISDA Master agreement, ${ }^{27}$ often contain several (and overlapping) non-exclusive jurisdiction clauses providing not only for London but also for Frankfurt and other courts on the Continent. ${ }^{28}$

Therefore, it can be expected that soon after Brexit, there will be disputes that will simply be brought to Frankfurt rather than to London even under existing agreements. No start from scratch is necessary, in the sense of parties having to agree on new jurisdiction clauses. Rather, the opportunity for an isolated change of the choice-of-court clause already exists, and with a mind towards Brexit-related uncertainties, parties might

22. Best practices in Düsseldorf include the publication of as many decisions as possible to allow for more predictability, as well as limiting expert witnesses to speed up proceedings. For more details, see Bechtold, Frankenreiter \& Klerman, above n. 6, at $17 \mathrm{ff}$.

23. This refers to the active application of overarching principles anchored in the ZPO, especially the principle of accelerating the proceedings ('Beschleunigungsgrundsatz').

24. S. Vogenauer, 'Regulatory Competition through Choice of Contract Law and Choice of Forum in Europe: Theory and Evidence', in H. Eidenmüller (ed.), Regulatory Competition in Contract Law and Dispute Resolution (2013), at $227 \mathrm{ff}$.

25. At the Singapore Commercial Court, the first 'genuine' case based on a choice of court agreement reached the Court in 2018. However, the president of the Singapore Court allocated earlier cases to the Commercial Court.

26. Information provided by Judge Willoughby (sitting judge in the Chamber for International Commercial Disputes) to the author.

27. See B. Hess, 'The Private Public Divide in International Dispute Resolution', Recueil des cours 388 (2018), 39, paras. 127 f. (2018). Recently, the ISDA has changed the jurisdiction and choice-of-law clauses in the ISDA Master Agreement to Dublin and Paris and to Irish and French law in order to accommodate the legal consequences of Brexit.

28. On the topic of non-exclusivity of choice of court agreements, see B. Hess, 'Die Auslegung kollidierender Gerichtsstandsklauseln im europäischen Zivilprozessrecht', in M. Brinkmann et al. (eds.), Dogmatik im Dienst von Gerechtigkeit, Rechtssicherheit und Rechtsentwicklung: Festschrift für Hanns Prütting (2018) 337, at 343 f. already prefer to choose a court in Ireland, France, the Netherlands or Germany. ${ }^{29}$

Several specific elements of the justice initiative stand out: ${ }^{30}$ Firstly, the Chamber will be composed of justices who possess both extensive experience in commercial litigation and a good command of English. In England, justices are usually recruited from the bar and understand the parties' perspective towards litigation. Similarly, in Frankfurt, some justices have moved from the bar to the bench. ${ }^{31}$ Furthermore, the staff of the Geschäftsstelle of the Chamber will equally be able to communicate in English and process the respective documents. In addition to this, modern technical equipment and an IT framework will support the desired service-friendly environment. With German courts lagging behind other European countries in this respect, this is an area with much room for improvement.

\subsection{The Process Design}

The process design of civil proceedings for the Frankfurt Chamber of International Commercial Matters has to follow the regulations of the German Code of Civil Procedure in the first instance (sections 253-300 ZPO). However, these provisions permit efficient and speedy management of the proceedings:

Starting with the filing of a written complaint (Klage), the plaintiff must specify their claims for relief as well as the facts of the case and the means of evidence supporting the factual allegations. After the filing of the complaint, the judge may conduct a preliminary review of the complaint (if any) to ascertain if the fundamental requirements of admissibility (Prozessvoraussetzungen) are met. ${ }^{32}$ When the defendant has filed their motion, the judge usually decides whether there will be a discussion at an advance first hearing (früher erster Termin $)^{33}$ or an exchange of written pleadings and briefs (schriftliches Vorverfahren $)^{34}$ to prepare the case for disposition in the hearing. At this stage of the proceedings, the court may also require additional documentary evidence or acquiescence in the inspection of evidence both from the par-

29. According to recent estimates of the Law Society for England and Wales, in almost 33 per cent of all commercial transactions concluded after Brexit, choice-of-court clauses have been changed from London to other jurisdictional hubs as Paris, Dublin, Amsterdam and Frankfurt; seehttps://www.lawgazette.co.uk/businesses-shun-uk-courts-indroves-as-brexit-looms/5066997.article.

30. For further details, see also the portrayal of the Justice Initiative Frankfurt at http://conflictoflaws.net/2017/the-justice-initiative-frankfurtam-main-2017-law-made-in-frankfurt/.

31. This is the typical situation in England.

32. This does not include the requirement of jurisdiction. Pursuant to Art. 26 of the Brussels Ibis Regulation, if the plaintiff files the complaint before a court lacking jurisdiction, the defendant may object to the lack of jurisdiction of the court. If the defendant fails to do so, the competence of the court is established by the fact that the defendant makes an appearance.

33. If the court decides on an advance first hearing (section $275 \mathrm{ZPO}$ ), it sets a time for the advance first hearing, where the judge discusses the issues argued in the complaint with the parties and their counsel; see P. L. Murray and R. Stürner, German Civil Justice (2004), at 13.

34. Pursuant to section $276 \mathrm{ZPO}$, if the court decides not to schedule an advance first hearing, the defendant will be served the complaint and should notify the court about his intention to defend within two weeks; see Murray and Stürner, above n. 33, at 12. 
ties and even from third parties. Section 273 of the Code of Civil Procedure allows the court to prepare the case by structuring, clarifying and narrowing down factual and legal issues in order to dispose of the case in one single hearing. ${ }^{35}$ Before the hearing, the court may schedule a settlement conference with parties and their lawyers in anticipation of amicably settling the case. Having prepared the case, the court may use its knowledge of the parties' respective contentions to propose a suitable settlement. ${ }^{36}$ If no settlement is reached, the case immediately goes to the plenary proceedings. At the beginning of the oral hearing, the presiding judge usually summarises the state of the dispute and structures the issues to be addressed. Usually, the parties (and their counsel) will have the opportunity to express their views. If there still are disputed facts, the taking of evidence follows, where the court assesses the means of evidence designated by the parties for any litigious allegation. Beforehand, the court may order the parties to produce relevant documents and tangible evidence to clarify factual assertions (sections 142-144 ZPO). ${ }^{37}$ Once all relevant legal and factual issues have been clarified, the court will discuss the disputed issues with the parties before rendering the judgment.

With regard to the process design itself, the Justizinitiative proposed that the Chamber for International Commercial Disputes borrow best practices from patent litigation $^{38}$ and international commercial arbitration. As in arbitration, the court should establish a 'road map' with the parties at the beginning of the process; this would structure the course of the litigation. The first hearing would function as a 'Case Management Conference' with the parties. Additionally, best practices of patent litigation should serve as a model for how the court should actively exercise its obligation under section 139 of the German Code of Civil Procedure, to better structure legal and factual allegations made and to engage in a 'discourse' with the parties about open legal and factual issues needing clarification before the hearing. ${ }^{39}$ It is

35. 'Section 273 - Preparations for the hearing

1. The court is to initiate the necessary preparatory measures in due time.

2. By way of preparing for the hearing, the presiding judge or a member of the court hearing the case delegated by the presiding judge may in particular:

1. Direct the parties to amend their preparatory written pleadings or to provide further information, and may in particular set a deadline for explanations to be submitted regarding certain items in need of clarification;

2. Request that public authorities or public officials communicate records or provide official information;

3. Order parties to appear at the hearing in person;

4. Summon witnesses, to whom a party has referred, and experts to appear at the hearing, he may also issue an order pursuant to section 378;

5. Issue orders pursuant to section 142 and section 144. [...]'

36. O. Jauernig and B. Hess, Zivilprozessrecht (2011), at 189 ff.; Murray and Stürner, above n. 33, at 13.

37. Jauernig and Hess, above n. 36, at 208 f.; Murray and Stürner, above n. 33, at 14 .

38. For an analysis of the driving factors of court popularity in patent litigation, see Bechtold, Frankenreiter \& Klerman, above n. 6, at $17 \mathrm{ff}$.

39. 'Section 139 - Direction in substance of the course of proceedings undeniable that the length of proceedings largely depends on thorough preparation of the hearing by the court and the parties. Another important procedural tool relates to the increased use of sections $142^{40}$ and 144 ZPO. ${ }^{41}$ These provisions enable a (structured) exchange of all pertinent evidence between the parties under the control of the court ('German disclosure'), usually at the preparatory stage of the hearing. In general, it is the parties' duty to provide the court with the relevant evidence for the substantiation of material facts asserted by the parties. However, sections 142 and 144 ZPO permit the court to assist the parties in the production of evidence, complementing section 139 ZPO. ${ }^{42}$

Section 142 (1) ZPO allows the court to direct the parties or a third party ${ }^{43}$ to produce records or docu-

1. To the extent required, the court is to discuss with the parties the circumstances and facts as well as the relationship of the parties to the dispute, both in terms of the factual aspects of the matter and of its legal ramifications, and it is to ask questions. The court is to work towards ensuring that the parties to the dispute make declarations in due time and completely, regarding all significant facts, and in particular is to ensure that the parties amend by further information those facts that they have asserted only incompletely, that they designate the evidence, and that they file the relevant petitions.

2. The court may base its decision on an aspect that a party has recognisably overlooked or has deemed to be insignificant, provided that this does not merely concern an ancillary claim, only if it has given corresponding notice of this fact and has allowed the opportunity to address the matter. The same shall apply for any aspect that the court assesses differently than both parties do.

3. The court is to draw the parties' attention to its concerns regarding any items it is to take into account ex officio. [...]'

The purpose of this provision is to realize numerous principles of the German civil procedure, e.g. the right to be heard ('Anspruch auf rechtliches Gehör') and the right to a fair hearing ('Recht auf ein faires Verfahren'), the achievement of a correct judgment ('Erzielung eines richtigen Prozessergebnisses') as well as the principle of accelerating the proceedings ('Beschleunigungsgrundsatz'). Following from the duty of the court to accelerate and economise proceedings in consultation with the parties, the court has to give the respective notice at the earliest possible time, either orally or written; see J. Fritsche, '§ 139 Materielle Prozessleitung', in T. Rauscher and W. Krüger (eds.), Münchener Kommentar ZPO (2016), at paras. 2 and $52 \mathrm{f}$.

40. 'Section 142 - Order to produce records or documents

1. The court may direct one of the parties or a third party to produce records or documents, as well as any other material, that are in its possession and to which one of the parties has made reference. The court may set a deadline in this regard and may direct that the material so produced remain with the court registry for a period to be determined by the court. [...]'

41. 'Section 144 - Visual evidence taken on site; experts

1. The court may direct that visual evidence is to be taken on site, and may also direct that experts are to prepare a report. For this purpose, it may direct that a party to the proceedings or a third party produce an object in its possession, and may set a corresponding deadline therefor. The court may also direct that a party is to tolerate a measure taken under the first sentence hereof, unless this measure concerns a residence. [...]'

These sections allow the judge to clarify incomplete party submissions, thus reducing the risk of delays at later stages of the proceedings. See J. Fritsche, '§ 144 Augenschein; Sachverständige', in T. Rauscher and W. Krüger (eds.), Münchener Kommentar ZPO (2016), at paras. 1, 20, 23.

42. Fritsche, above n. 41 , at para. 1 .

43. With regard to third parties, the court has to consider, within its direction, limits of reasonableness, e.g. for highly personal materials, as well as rights to refuse to give evidence. See A. Baumbach, W. Lauterbach, J. Albers \& P. Hartmann, '142 Anordnung der Urkundenvorlegung', Zivilprozessordnung (2019), at para. 4 
ments, ${ }^{44}$ as well as any other material ${ }^{45}$ in their possession to which one of the parties has made reference. These orders contribute to the provision of information to the court as well as to the uncovering of evidence to elucidate litigious facts. ${ }^{46}$ The court's discretion is, however, limited by the submissions of the parties. ${ }^{47}$ Section 144 (1) ZPO aims to clarify litigious facts ${ }^{48}$ by allowing the court to direct that an expert take visual evidence on site ${ }^{49}$ and prepare a report for the hearing. ${ }^{50}$ The court's direction may be issued to the parties and even to third parties. ${ }^{51}$

Prospectively, this set of provisions, which is broadly used in patent litigation and which enables the court to actively direct proceedings, should equally benefit cases before the Chamber for International Commercial Disputes. In addition, borrowing from practices in commercial arbitration, the 'Justizinitiative' proposed the preparation of a full recording of the hearing, along with the transmission of a textual record to the parties as an electronic document (see sections 160-164 of the Code of Civil Procedure).$^{52}$

Finally, using English as the language of litigation would reduce costs of litigation and increase effectiveness by eliminating translations - for instance, by hearing witnesses in their mother tongue or the language of international commercial exchange. Judges should prepare the judgments in a manner that allows for their speedy translation into other languages. This issue carries particular weight, since under current legislation, the judgment of a German court must be drafted in German. In addition, even after a change of the legislation, there will always be a need to translate the operative part of a judgment into German for enforcement purposes. Currently, the language and style used in German judgments often make them unfit for resourceefficient translation. Thus, it is crucial to promote the drafting of decisions using translation-friendly wording. Overall, it appears that establishing chambers for international commercial matters mainly requires a practical approach.

44. Section 142 (1) ZPO extends to all records and documents according to sections $415 \mathrm{ff}$. ZPO.

45. This refers to materials without document character, such as image, data and sound carriers. See Baumbach, Lauterbach, Albers \& Hartmann, above n. 43, at para. 10.

46. Bundesgerichtshof, 16 March 2017 - I ZR 205/15, 45 NJW 3304 (2017); on the limits of section 142 ZPO: Bundesgerichtshof, 27 May 2014 - XI ZR 264/13, 45 NJW 3312 (2014)

47. The latter is following from the principle of party control over the cause of action. See Fritsche, above n. 41, at paras. 2 and 4.

48. D. von Selle, ' $\S 144$ Augenschein; Sachverständige', in V. Vorwerk and C. Wolf (eds.), BeckOK ZPO (2018), at para 1; A. Stadler, '§ 144 Augenschein; Sachverständige', in H.-J. Musielak and W. Voit (eds.), Zivilprozessordnung: ZPO (2018), at para 1

49. According to section $371 \mathrm{ZPO}$, the evidence taken by visual inspection is offered by designating the object to be inspected visually and by citing the facts regarding which evidence is to be provided.

50. According to sections $402 \mathrm{ff}$. ZPO.

51. The same limits apply to directions issued to third parties under section 144 ZPO as to directions under section 142 ZPO; see A. Baumbach, W. Lauterbach, J. Albers \& P. Hartmann, '144 Augenschein; Sachverständige', Zivilprozessordnung (2019), at para. 15.

52. These provisions regulate the protocol of the hearing.

\subsection{The Implementation of the Concept}

Interested parties can easily follow the implementation of the procedural elements of the 'Justizinitiative': The homepage of the District Court of Frankfurt contains a link to a web page for the 'Chamber for International Commercial Disputes ${ }^{53}$ that contains information about the proceedings before the Chamber and is available in English $^{54}$ and in German. The distribution list, also available on the District Court website, ${ }^{55}$ contains the names of judges who are responsible for those proceedings. This distribution list also includes a first definition of international commercial affairs: ${ }^{56}$

Proceedings, which are under the jurisdiction of a Chamber for Commercial Disputes and not under a special jurisdiction of another Chamber of the Court will be referred to the Chamber for International Commercial Disputes, if the lawsuit has a bearing upon an international matter and the parties declare before the end of the deadline for the statement of defence that they would like to plead in the oral hearings in English and waive the right to have an interpreter.

This basic provision permits hearings to be conducted in English. According to the provision, there must be a commercial dispute, ${ }^{57}$ which is at the same time an international matter. Even though the distribution list does not define the term 'international matter', the legal proposal to amend the Courts Constitution Act, ${ }^{58}$ however, addresses this issue by mentioning some examples covered by this term. ${ }^{59}$ Moreover, there must be a declaration of the parties that they want to litigate the dispute before this chamber. Additionally, the distribution list indicates that a panel of three judges constitutes the chamber: either Judge Ulrike Willoughby or Dr. Felix Bergmeister sit as presiding judge along with two commercial lay judges from the business sector who are expert in finance, banking, accounting, insurances,

53. See the website of the district court of Frankfurt, available at: https:// ordentliche-gerichtsbarkeit.hessen.de/LG-Frankfurt (last visited 5 December 2018)

54. Available at: https://ordentliche-gerichtsbarkeit.hessen.de/ordentlichegerichte/lg-bezirk-frankfurt-m/lg-frankfurt-m/chamber-internationalcommercial-disputes (last visited 4 October 2018).

55. See the distribution list, at 84 , available at: https://ordentlichegerichtsbarkeit.hessen.de/sites/ordentliche-gerichtsbarkeit.hessen.de/ files/LG\%20FFM\%20Gesch\%C3\%A4ftsverteilung \%202018\%20Stand $\% 2001.01 .2018$.pdf.

56. See the distribution list, above n. 55, at 35.

57. Corresponding to section 95 GVG.

58. Entwurf eines Gesetzes zur Einführung von Kammern für internationale Handelssachen (KfiHG), Bundestagsdrucksache 19/1717, 18 April 2018, proposed section 114b GVG.

59. Entwurf eines Gesetzes zur Einführung von Kammern für internationale Handelssachen ( $\mathrm{KfiHG}$ ), above n. 58, at 14. Regarding the proposed section 114b GVG, the draft states that an 'international matter' is given, e.g. if the contractual agreements or contract documents are written in English, if a party is domiciled abroad or if foreign law applies. The same is assumed in internal company disputes if the company's internal contracts and correspondence are in English or if the company is domiciled abroad. It is noteworthy that German law does not give the parties the possibility to agree on qualifying their (domestic) disputes as 'international'. 
transportation and so on and often have a strong legal background, too.

The description of the proceedings on the District Court web page simultaneously serves as an advertisement demonstrating that the Frankfurt District Court offers a well-equipped and efficient infrastructure for commercial litigation. This is also reflected in the regulations on the design of the process, which underline the duty (and willingness) of the court to suitably structure and accelerate the proceedings where appropriate. ${ }^{60}$ To do this, the chamber will set a time frame in an initial early hearing that serves as a kind of non-technical case management conference, thus enabling the court to manage the proceedings in a clear and transparent way. Key provisions for this are sections $273 \mathrm{ZPO}^{61}$ and $275^{62}$ $\mathrm{ZPO}$, which require the court to actively prepare both the advance and, if necessary, the main hearing, e.g. by ordering the parties to appear in person and by requesting missing information from the parties ${ }^{63}$ and from public authorities. Additionally, the court will remain active in directing the proceedings, using the leeway granted by a number of key provisions in the German Code of Civil Procedure. ${ }^{64}$ Provisional relief is also available when the successful execution of a future civil

60. This duty is commonly associated with section 139 ZPO (see above n. 35) but permeates all judicial actions. It is important to note that this does not mean that the court will clarify facts of the case out of selfmotivation and without regard for the parties. Rather, the duty is understood to be a 'duty to provide hints and feedback' to the parties in order to protect them from surprise and avoid unnecessary delays at later stages of the proceedings. See Murray and Stürner, above n. 33, at 166; Jauernig and Hess, above n. 36, at $100 \mathrm{ff} ., 117$.

61. See above n. 35 .

62. 'Section 275 - Advance first hearing

1. By way of preparing for the advance first hearing, the presiding judge or a member of the court hearing the case delegated by the presiding judge may set a deadline for the defendant by which he is to submit a written statement of defence. Alternatively, the defendant is to be instructed to have an attorney he is to appoint submit to the court, in a written pleading and without undue delay, any means of defence that are to be brought before the court; section 277 (1), second sentence, shall apply mutatis mutandis.

2. Should the proceedings not be conclusively dealt with and terminated at the advance first hearing, the court shall issue all orders still required to prepare for the main hearing for oral argument.

3. At the advance first hearing, the court shall set a deadline for submitting a written statement of defence should the defendant not yet have responded to the complaint at all, or not sufficiently, and wherever no deadline pursuant to subsection (1), first sentence, had been set.

4. At the advance first hearing, or upon having received the statement of defence, the court may set a deadline for the plaintiff within which he is to state his position in writing as regards the statement of defence. The presiding judge may set such deadline also outside of the hearing.'

63. An increased use of sections 142 and 144 ZPO (above n. 40 and n. 41) in the preparations for the hearing, as explicitly mentioned in section 273 (2) n. 5 ZPO (above n. 35), allows the court to direct a structured exchange of evidence between the parties ('German disclosure') if there is a contested issue of fact. See Murray and Stürner, above n. 33, at $225 \mathrm{f}$.

64. Inter alia this includes the general permission of written preparation statements of witnesses (section 377 (3) ZPO) and the recording of the hearing and preparation of a textual record (sections 160-164 ZPO), as an electronic document. Patent litigation chambers serve as an example regarding the use of these provisions, as described by Bechtold, Frankenreiter \& Klerman, above at n. 6. judgment might be hindered by the lapse of time or intervening events. The German Code of Civil Procedure provides the possibility to initiate special proceedings for prejudgment attachment (Arrest) $)^{65}$ and other preliminary measures (einstweilige Verfügung). ${ }^{66}$ In both cases, the competent court is the court before which the main action is being pursued, ${ }^{67}$ thus ensuring that these proceedings will still be held in English.

\section{The (Re-)Current Legislative Proposals to Amend the German Courts Constitution Act (GVG)}

Changes to the German Courts Constitution Act are currently under discussion. As described above, the present legal regime provides in section 184 (1) of the German Courts Constitution Act $^{68}$ that 'The language of the court shall be German.' Correspondingly, section 185 (1) enables the parties to call for an interpreter when they do not have a sufficient command of the German language ${ }^{69}$ However, section 185 (2) allows for an interpreter to be dispensed with if all persons involved have a sufficient command of the foreign language. ${ }^{70}$ Using this slender provision has made it possible to establish English proceedings in German courts. However, strictly verbatim, it only permits the conduct of the hearing in English, although an expansion by analogy to the written phase of the proceedings is possible. ${ }^{71}$ Nonetheless, from a legalistic point of view, more clarification is needed, and there are ongoing proposals ${ }^{72}$ to reform the German Courts Constitution Act accordingly. Currently, a third attempt to reform the permissible court language has been submitted to the German Parliament as

65. Sections $916 \mathrm{ff}$. ZPO; see Murray and Stürner, above n. 33, at $434 \mathrm{ff}$.

66. Sections 890, 935 ff., 940 ZPO; see Murray and Stürner, above n. 33, at $437 \mathrm{ff}$.

67. Pursuant to section 919 ZPO (in the case of prejudgment attachments: the local Amtsgericht is also responsible) and section 937 ZPO (in the case of other preliminary measures).

68. See the wording supra at fn. 14.

69. Section 185 GVG reads as follows: '(1) If persons are participating in the hearing who do not have a command of the German language, an interpreter shall be called in. No additional record shall be made in the foreign language; however, testimony and declarations given in the foreign language should also be included in the record or appended thereto in the foreign language if and to the extent that the judge deems this necessary in view of the importance of the case. Where appropriate, a translation to be certified by the interpreter should be annexed to the record. [...] (2) An interpreter may be dispensed with if all the persons involved have a command of the foreign language. [...]'.

70. However, written pleadings and court records must be drafted in German. On the (limited) scope of section 185 (2) GVG, see J. Riedel, 'Englisch als Verhandlungssprache vor Gericht', in M. Habersack et al. (eds.), Festschrift für Eberhard Stilz zum 65. Geburtstag (2014) 501, at 502 f.

71. I.e. on initiative of the court or the parties, parties might renounce the translation of documents that are submitted as evidence to the court.

72. Bundesratsdrucksache 53/18 (Beschluss) = Entwurf eines Gesetzes zur Einführung von Kammern für internationale Handelssachen (KfiHG), above n. 58. 
a legislative proposal. While the previous lack of success attests to a certain resistance in the German Parliament to using a foreign language in court proceedings, ${ }^{73}$ it warrants mentioning that this time several major Federal States, including Bavaria, Hesse, North Rhine-Westphalia, Lower Saxony and Hamburg, are backing the initiative. Moreover, various administrative arms are supporting the project, including the Federal Ministry of Justice. As the current term of the Federal Parliament has started relatively recently, there are good prospects that this time, the proposal will be successful.

Inter alia, the proposal provides for the amendment of section 184 (2) and (3) of the German Courts Constitution Act and reads as follows:

(2) Before the International Chambers for Commercial Disputes and the Higher Regional Courts competent for appeals and complaints against these decisions the proceedings shall be conducted in English. In these proceedings, the minutes and the decisions of the Court shall also be drawn in English. The operative parts of judgments and resolutions must be translated into German when they have an enforceable content (...).

(3) In international commercial matters, the proceedings before the Federal Court of Justice may be conducted in English.

Once the amendment enters into force, courts of the first and second instance will conduct not only the oral hearings but the whole proceedings in English, based on the parties' consent. The situation will be different at the Federal Civil Court (Bundesgerichtshof), where the proceedings may be conducted in English at the discretion of the court. ${ }^{74}$ However, it is worth noting that if foreign law is applicable on the substance, e.g. English law or Irish law, the Federal Civil Court does not have jurisdiction to review appeals based on the violation of foreign law. ${ }^{75}$ Ending up with only two instances and reducing appeal by limitation to 'two shots' might also speed up the proceedings, although it is doubtful whether this would serve the interest of the parties. ${ }^{76}$

73. The lack of success of the previous proposals (see above n. 18) can also be attributed to the end of the respective legislative periods, although a project of higher political priority (at the time) might not have fallen victim to parliamentary scheduling issues.

74. This provision demonstrates an ongoing reluctance within the Bundesgerichtshof with regard to the project.

75. The Federal Court does not review the application of foreign law, Bundesgerichtshof, 4 July 2013 - V ZB 197/12, 50 NJW 3656 (2013); see also W. Krüger, ' $\$ 545$ Revisionsgründe', in T. Rauscher and W. Krüger (eds.), Münchener Kommentar ZPO (2016), at para. $11 \mathrm{f}$. However, this principle has been called into question in the wake of a 2009 reform; see B. Hess and R. Hübner, 'Die Revisibilität ausländischen Rechts nach der Neufassung des § 545 ZPO', 43 NJW 3132 (2009). Additionally, a review appeal may still be based on incorrect application of evidentiary rules when ascertaining the contents of foreign law, see Murray and Stürner, above n. 33, at $392 \mathrm{f}$.

76. This has, however, also attracted criticism based on the notion that if the parties choose a German forum, they should also be able to access the 'full range' of the German judicial system, i.e., including a possible review appeal. Ideally, this would be accompanied by a choice of substantive German law, as argued by $M$. Siegmann, 'Ein richtiger erster
Additionally, a definition of 'international commercial matters' will be included in section $114 \mathrm{~b}$ of the German Courts Constitution Act. ${ }^{77}$ Furthermore, there will be a provision in section 95 of the German Courts Constitution Act empowering the Federal States, which are responsible for the administration of justice to establish international chambers for commercial matters.

There is also an interesting provision concerning situations when a third-party notice is filed. In this constellation, the third party might contest proceedings conducted in English and the obligation to participate in those proceedings and has a right to request that the proceedings are continued in German.

Nevertheless, one issue remains in the legislative project: If the proceedings are conducted in English, this has to apply also to the complaint, which is the first step to start court litigation.

Therefore, to achieve the desired results, the German Courts Constitution Act must be amended in three respects: to allow the complaint also to be filed in English, to include the possibility for the defendant to lodge an appeal and to give the third party the right to request for German-language proceedings.

Such a mechanism is already envisaged in the proposed amendment of section 73 of the Code of Civil Procedure, which takes up the provisions of Article 8 of the Service Regulation ${ }^{78}$ dealing with foreign languages and the right of the addressee to refuse the acceptation of a document drawn up in a language the addressee does not understand. A similar provision should apply to section 253 of the Code of Civil Procedure, which addresses the content of the lawsuit: The plaintiff should be allowed to draft the complaint in English, but the defendant will have two weeks from the acceptance of such a complaint to contest the conduct of proceedings in English. Furthermore, this amendment would ensure a level playing field for the service of documents both at the European level and in domestic cases.

\section{Similar Initiatives at Other Courts in Germany}

It remains to be mentioned that Frankfurt is not the only place in the sixteen Federal States in Germany

Schritt auf einem langen Weg', 4 Deutscher AnwaltSpiegel 17, at 23 (2018).

77. Entwurf eines Gesetzes zur Einführung von Kammern für internationale Handelssachen (KfiHG), above n. 58.

78. Regulation (EC) No 1393/2007, OJ L 324. 'Article 8 reads as follows: (1) The receiving agency shall inform the addressee, using the standard form set out in Annex II, that he may refuse to accept the document to be served at the time of service or by returning the document to the receiving agency within one week if it is not written in, or accompanied by a translation into, either of the following languages:

a. a language which the addressee understands; or

b. the official language of the Member State addressed or, if there are several official languages in that Member State, the official language or one of the official languages of the place where service is to be effected. [...]' 
where initiatives have popped up. Similar initiatives are found in Hamburg and in Düsseldorf:

A press release ${ }^{79}$ on the website of the Hamburg judiciary states that, as of May 2018, proceedings can also be conducted in English, at least in oral hearings. Unfortunately, the website is only in German. In the distribution list of the District Court, ${ }^{80}$ however, no link to the chamber for international commercial affairs has been included so far. At present, it remains unclear whether the chamber has already been established.

Similar developments are happening in Düsseldorf, ${ }^{81}$ where debates about the establishment of international chambers for commercial matters have already been launched.

\section{The 2018 Initiative for Expedited B2B Procedures of the EU-Parliament: Is an Additional European Initiative Needed?}

Developments on the European level are also progressing: An expert hearing by the Committee on Legal Affairs of the European Parliament took place on 9 July 2018, addressing the issue whether the European Union should introduce expedited procedures for international commercial disputes. ${ }^{82}$ Even if the eventual conclusion is that there is no need for an additional European procedure for commercial disputes, the Parliament could still encourage the Member States to establish commercial courts, as it did in the case of collective redress.

Another idea could be to enlarge the scope of application of the Small Claims Regulation again to include more cross-border cases, even if the Small Claims Regulation might not be the best instrument for handling cross-border disputes. Other interesting ongoing projects include a model code of civil procedure, which is

79. Available at: https://justiz.hamburg.de/pressemitteilungen/10983386/ pressemitteilung-2018-04-30-olg-01/.

80. The distribution list of 2018 is available at: https://justiz.hamburg.de/ contentblob/10958882/bf3019196ec6c143e66325b4263bc793/data/ geschaeftsverteilungsplan-2018-stand-02-01-2018.pdf.

81. See R. Podszun and T. Rohner, Staatliche Gerichte für wirtschaftsrechtliche Streitigkeiten stärken: Ein "Düsseldorf Commercial Court" als Antwort auf den Brexit (2017), available at: http://www.jura.hhu.de/ fileadmin/redaktion/Fakultaeten/Juristische_Fakultaet/Podszun/ Podszun Rohner_Paper_Staatliche Gerichte staerken.pdf; see also the press release of the Minister of Justice in North Rhine-Westphalia, Peter Biesenbach, on the topic of strengthening commercial courts in North Rhine-Westphalia (such as the district court Düsseldorf), available at: https://www.justiz.nrw/JM//Presse/reden/archiv/2018_01_Archiv/ 2018_03_28_Sprechzettel_Minister_Pressefruehstueck/index.php.

82. The hearing was prepared by a study for the European Parliament, cf. G. Rühl, Building Competence in Commercial Law in the Member States (PE 604.980). being prepared by the European Law Institute and UNIDROIT $^{83}$ and supported by the most eminent proceduralists in Europe. This project might also provide some inspiration for improvements to national proceedings.

The most ambitious proposal relates to the establishment of a genuine European Commercial Court, similar to the European patent litigation system. ${ }^{84}$ This proposal was originally made by Professor Thomas Pfeiffer ${ }^{85}$ and has been recently taken up again by Professor Giesela Rühl. ${ }^{86}$ They propose that the court should be composed of judges from different EU Member States and provide for two instances. Giesela Rühl sees the main added value to be in its character as a 'truly international forum'. ${ }^{87}$ Yet, it remains to be seen whether the court will act truly internationally as it shall apply the EU private international law instruments, which eventually refer to national law. If national law applies to the merits, at least two members of an international bench composed of three judges might not be familiar with it. ${ }^{88}$ In addition, there is a considerable legal impediment as the European Union has no legislative competence to establish a supranational civil court outside of the system of the CJEU. ${ }^{89}$ Nevertheless, this proposal demonstrates that the recent developments have triggered a lively debate.

\section{Conclusions/Outlook}

Overall, the ongoing expansion of cross-border dispute settlement will perhaps not entail the establishment of a European Commercial Court. However, if it results in several international commercial courts in the European Member States, this might also be considered a successful outcome. There will be, of course, more competition, but in a positive sense of the term: learning the best from other countries, improving one's own procedures by adapting the old procedures and taking up the best practices from abroad. In the end, the reforms may also help to improve the national procedural systems in general, e.g. by transferring best practices to domestic civil litigation. In this case, not only commercial parties

83. See https://www.unidroit.org/work-in-progress-eli-unidroit-europeanrules, for more details on the history and regular updates on the state of the project (last visited 4 October 2018).

84. A similar proposal was made by $\mathrm{G}$. Wagner with regard to the creation of 'true German Commercial Court' as a common court of all or several Federal States, cf. Wagner, Rechtsstandort Deutschland im Wettbewerb (2017), at $232 \mathrm{ff}$. Yet, the federal structure of the justice system in Germany does not really permit the establishment of one centralised court (which eventually should be conceived as a federal court).

85. T. Pfeiffer, 'Ein europäischer Handelsgerichtshof und die Entwicklung des europäischen Privatrechts', ZEuP 795, at 797 ff. (2016).

86. Rühl, above n. 82 , at 58-64.

87. Rühl, above n. 82 , at 58 .

88. As a result, there might be even less expertise in the court compared to a commercial court applying its own law.

89. The problems are described by Rühl, above n. 82 , at $59 \mathrm{f}$. (discussing Arts. 257 and 81 TFEU). However, Art. 81 TFEU does not open up a competence of the EU for the establishment of a genuine supranational court; contrary opinion, Rühl, above n. 82, at 60 . 
but all litigants would eventually profit from improvements and reforms that are triggered by the practices developed in the chambers for international commercial disputes. 